Int. J. Morphol.,

36(3):1087-1094, 2018.

\title{
Catha edulis Forsk Mediates Embryotoxic Effects in Rats: An Experimental Study
}

\author{
Catha edulis Forsk Modera los Efectos Embriotóxicos en Ratas: Un Estudio Experimental
}

\author{
Alaa Sayed Abou-Elhamd ${ }^{1,2}$; Hussein Ageely $^{3}$; Muhammad Abu-Elmagd ${ }^{4}$ \& Ahmed Elzuhry Zayed Ahe $^{1,2}$
}

\begin{abstract}
ABOU-ELHAMD, A. S.; AGEELY, H.; ABU-ELMAGD, M. \& ZAYED, A. E. Catha edulis forsk mediates embryotoxic effects in rats: An experimental study. Int. J. Morphol., 36(3):1087-1094, 2018.

SUMMARY: Catha edulis Forsk leaves (Khat) is a flowering plant. A high proportion of the adult population in the Arabian Peninsula and the Horn of Africa chews it for its mild stimulant effect. The aim of the current study was to investigate the embryotoxic and teratogenic effects of the Khat extract using 60 female pregnant rats. These were divided to a Khat extract-treated group and a control group. Methanolic extract of Khat was orally given to the treated group 4 days before mating and up to day 16 of pregnancy with a dose of $100 \mathrm{mg} / \mathrm{kg}$. Our results showed that significant number of embryos of the Khat-treated mothers were malformed and different in size and shape compared to embryos from the mothers of the control group. At day 8 of pregnancy, malformed embryos had ill developed primitive layers. By day 10 of pregnancy, neural tube and the somite were not formed compared to the control embryos. At later stages of pregnancy, embryos of the Khat-treated mothers appeared severely abnormal with opened neural groove and visceral pouches. Disrupted normal neural tube development, undifferentiated brain vesicles, incomplete closure of the brain flexures were also observed in these embryos. Highly significant increase in the number of the resorbed embryos of the Khat-treated mothers were observed ( $P<0.01)$. The resorbed embryos appeared as a cellular collection in their placenta with some of their decidua had no visible embryonic tissues. In conclusions, Khat induced embryotoxic effects as well as severely affected the early normal embryonic development in rat.
\end{abstract}

KEY WORDS: Khat; Embryo toxicity; Teratogenicity; Morphological \& Histological analysis; Rat.

\section{INTRODUCTION}

Khat plant (Catha edulis Forsk) belongs to the family Celastraceae (moonseed) that is frequently cultivated in certain regions of the horn of Africa and the Arabian Peninsula. The earliest scientific report about Khat was in the eighteenth century by the botanist Peter Forskal (AlHebshi \& Skaug, 2005) during his trip to Yemen. It has been estimated that about 20 million people worldwide use Khat as a pleasant mild stimulant (Al-Habori, 2005; El-Menyar et al., 2015).

Khat contains the alkaloids cathinone, norephedrin and cathine. The Khat's stimulant effect is mainly due to cathinone which has a similar mechanism of action to that of amphetamine and hence is considered as a natural amphetamine (Brenneisen et al., 1990; Kalix, 1996). Although the adverse systemic effects of Khat such as neurological disorders, hypertension, myocardial infarction, development of cancer and apoptotic changes in liver and kidneys (Al-Motarreb et al., 2002; Ageely et al., 2014; Ageely \& Abou-Elhamd, 2015) have been extensively studied, very little is known about the biological effects on cells (Carvalho, 2003). Studies on the effects of Khat on the developing neonates are scarce and only dealt with general aspects of embryonic development such as birth weight, length and head circumference (Eriksson et al., 1991; AbdEl-Aziz \& Ahmed, 1998).

Epidemiological studies carried out in Yemen showed that the occasional and regular mothers' users of Khat especially during pregnancy gave a significant low birthweight babies compared to the non- Khat users (Eriksson et al.). Neonates from the Khat-chewers' mothers had a significant decrease in all neonatal parameters such as birth weight, head circumference and Apgar score compared to

${ }^{1}$ Department of Anatomy, Histology and Embryology, Faculty of Veterinary Medicine, Assiut University, Assiut, Egypt.

${ }^{2}$ Department of Medical Laboratory Technology, Faculty of Applied Medical Sciences, Jazan University, Jazan, Saudi Arabia.

${ }^{3}$ Department of Internal Medicine, Faculty of Medicine, Jazan University, Jazan, Saudi Arabia.

${ }^{4}$ Centre of Excellence in Genomic Medicine Research, King Abdulaziz University, Jeddah, Saudi Arabia. 
the non-Khat-chewers' mothers (Hassan et al., 2007; AbdelAleem et al., 2015; Jerah et al., 2017). Trials for explaining the adverse effects of Khat consumption in pregnant women on neonatal growth have led to the suggestion that Khat induces an effect on the utero-placental blood flow and consequently impairs fetal growth and development (Jansson et al., 1987). In rat, pregnant mothers treated with high doses of Khat between days 6-15 showed fetal resorption, reduced embryo size associated, and congenital malformations (Islam et al., 1994). However, detailed histological analyses of these malformations at early and late stages of embryonic development were lacking. The aim of the current study was to analyze the cytotoxic and teratogenic effects of Khat extract on early and late development using rat model. We show that Khat induces different forms of embryo cytotoxic and teratogenic effects at different stages of development including uterine resorption, reduced litter size, and moderate to severely malformed affected embryo.

\section{MATERIAL AND METHOD}

Khat extraction. Fresh Khat bundles were kindly provided by Substances Abuse and Research Center, Jazan University. The fresh bundles were transported to the Biology Department, Faculty of Medicine for processing. Khat was extracted by Methanolic as previously described by (Dimba et al., 2004; Kimani et al., 2008). Briefly, the fresh Khat leaves were separated from the shoots, and washed thoroughly with distilled water, chopped on metal plates and finally crushed using a blender. Crushed material was immersed in sufficient amount of methanol (SigmaAldrich) and kept on rotary shaker for few hours. Filtration of the mixture was carried in two steps; firstly, using the gauze rolls to separate the larger particles and secondly with filtered throughout $11 \mathrm{~mm}$ filter (Grade 1, Whatman, Kent, UK). The non-filtered plant material was re-extracted in fresh methanol (Dimba et al.). The filtrate was collected in a beaker and kept overnight on magnetic stirrer at $45^{\circ} \mathrm{C}$ to completely evaporate the methanol (Kimani et al.), thus leaving dried material (i.e. the extract) which was kept as a powder at $4^{\circ} \mathrm{C}$. Fresh solution of Khat extract was prepared by dissolving the powder of Khat extract in distilled water, just prior to the daily oral administration to the rats. The concentration of Cathine and Cathinone were measured in Khat extract in Jazan poison control center (Jazan- Saudi Arabia). The concentration of Cathine was $305 \mu \mathrm{g} / \mathrm{ml}$ and that of the Cathinone was $114 \mu \mathrm{g} / \mathrm{ml}$

Animal grouping and dosing: Sixty Sprague-Dawley (SD) female rats weighting 180-200 g were used in this study.
The animals were housed in group cages and given free access to food and water. The rats were housed at $24{ }^{\circ} \mathrm{C}$ room temperature and $12 \mathrm{~h}$ light/dark cycle. All rats were acclimatized for one week before starting the Khat treatment. The rats were divided to two main groups each consists of 30 animals: 1- the Khat extract-treated group and 2- control (untreated Khat or distilled water treated) group. Each three females were housed with one male. A pregnant female was identified by the presence of the vaginal plug that forms after a successful mating by the male. This plug was usually visible by a simple visual examination of the valve and mostly persisted for 16-24 hours post-copulation. Once the plug was formed and seen, the day on which was considered as day 0 of pregnancy.

The Khat extract-treated group was daily given an oral dose of $100 \mathrm{mg} / \mathrm{kg}$ body weight Khat extract from 4 days before mating and up to day 16 of pregnancy. The control (untreated) group was orally given only distilled water (volume equal to that of the dose of extract in the previous group) daily throughout the period of the experiment. All rats were observed daily for any sign of toxicity during the course of the experiment until the sacrifice of the rats.

\section{Tissue preparation and examination:}

Sampling: After anesthesia by Isoflurane (Sigma Aldrich), 5 dams from each group were sacrificed at E-8, E-10, E-12, E-14, E-15 and E-16 days of pregnancy, then the chest and abdomen were opened, and few millimeters of blood were taken off from the heart to facilitate intracardiac infusion of the fixative; $4 \%$ paraformaldehyde in $0.1 \mathrm{M}$ Phosphate buffer solution was infused in the left ventricles of the heart to allow rapid fixation of the tissue.

Fixation and embedding: For histological examination, the uterus of each dam was examined for any morphological changes and then opened, and the embryos were taken out and immersed in $4 \%$ paraformaldehyde buffer and processed for paraffin embedding.

Sectioning, staining and examination: Paraffin-embedded embryos were sectioned using microtome (Leica Biosystems RM2245) at 5-7 $\mu \mathrm{m}$ thickness. Sections were stained by routine histological stain (Hematoxylin \& Eosin). The sections were examined and photographed using Olympus microscope with DP72 camera and cell software for imaging.

Ethical Approval. Ethical approval to carry out this study was obtained from the Research Ethics Committee of the Medical Research Center, Jazan University (REC/ MRC/ JU, 30/ 01/ 2017). 


\section{RESULTS}

Daily administration of Khat to pregnant rats at a dose $100 \mathrm{mg} / \mathrm{kg}$ body weight resulted in a highly significant increase in the mean number of the resorbed embryos $(\mathrm{P}<$ 0.01) compared to the control group (Fig. 1). This consequently resulted in a significant reduction in the number of live embryos in the Khat treated mothers when compared to the control untreated mothers (Fig. 2). No abortion cases were observed in the control as well as the Khat treated groups.

At day 8 of pregnancy, the control embryos showed that the three germ layers were formed and started the differentiation normally (Fig. 3A); while in the treated embryos the primitive layers were ill-developed (Fig. 3B).
At day 10 of pregnancy, the control embryos had nearly equal size and similar normal morphology with their somites and neural tube fully formed. Khat treated embryos had different sizes and shapes and their neural tube and the somites not formed (Figs. 4C-D). Trophoblast giant cells of different sizes and shapes were also observed.

At day 12 of pregnancy, control embryo appeared normal with closed visceral arches and cervical sinuses; tongue and limb buds formed, head folds were particularly prominent and neural closure occurred normally (Figs. 5A, B). Normal embryonic development was also including heart, liver, gut, and mesonephros (Fig. 5B). The embryos of the Khat-treated mothers appeared morphologically abnormal with different sizes

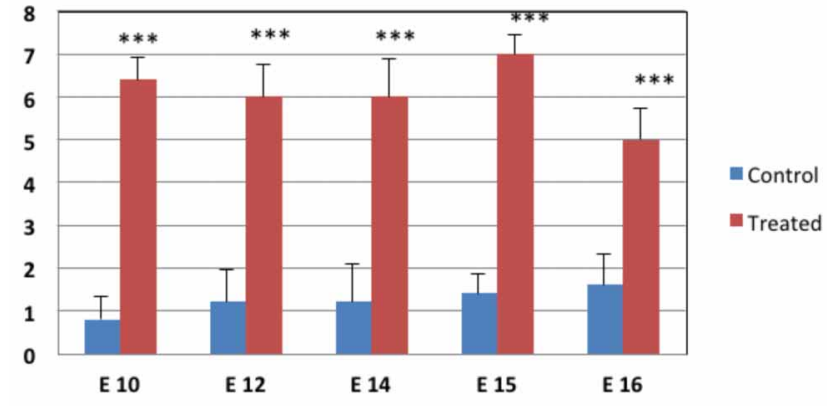

Fig. 1. Mean number of resorbed embryos. Graph showing a significant increase in the mean number of the resorbed embryos in the Khat treated mothers $(\mathrm{P}<0.01)$ compared to control.

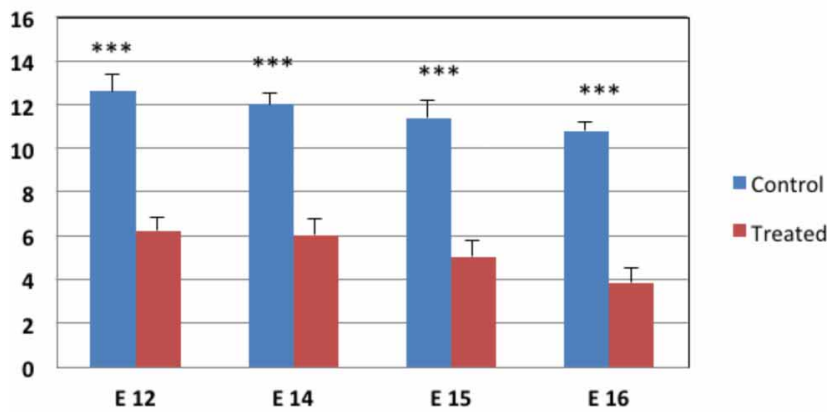

Fig. 2. Mean number of live embryos. Graph showing a significant reduction in the mean number of the live embryos in the Khat treated mothers $(\mathrm{P}<0.01)$ compared to control.
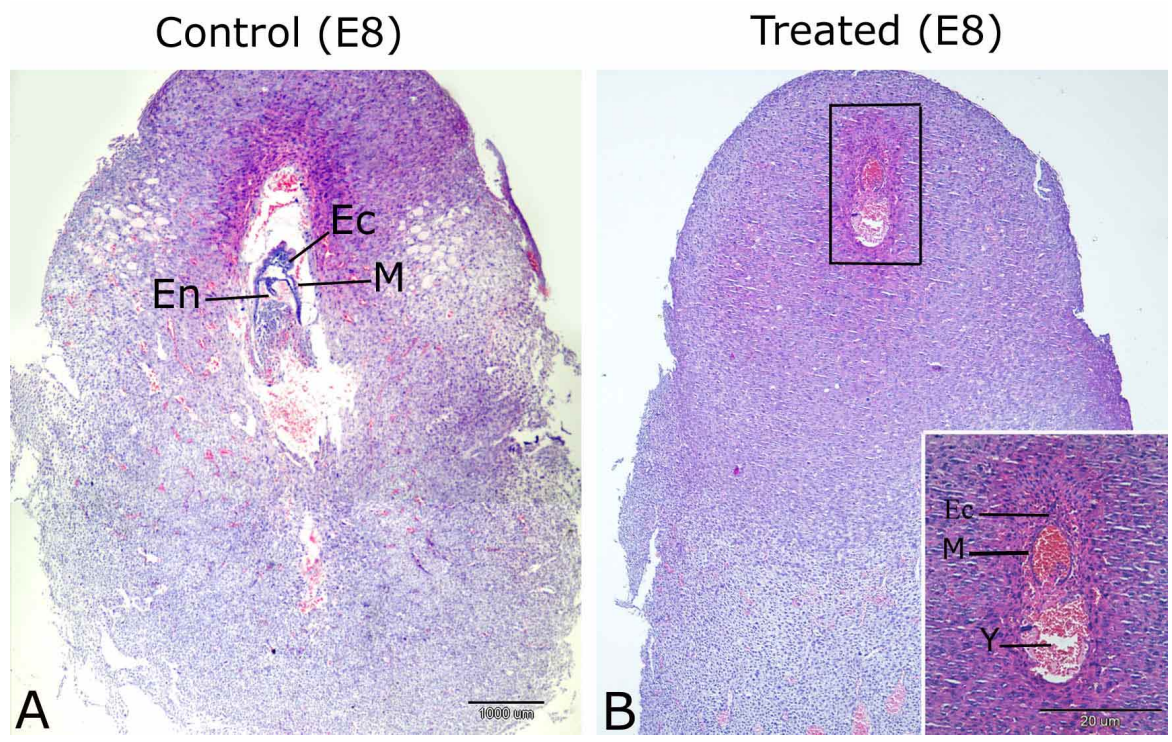

Fig. 3. E-8 Khat treatment outcome. (A): Sagittal section through E-8 control embryos showing normal development and differentiation of the three germ layers. (B): Sagittal section through a Khat-treated embryo after 8 days showing ill developed primitive layers. Ec, ectoderm; En, endoderm; M, mesoderm; Y, yolk sac. Inset: higher magnification of marked area in (B). Haematoxylin and Eosin stain, A\&B (scale bar $=100 \mu \mathrm{m}$ ); inset (scale bar $=20 \mu \mathrm{m})$. 
Control (E10)

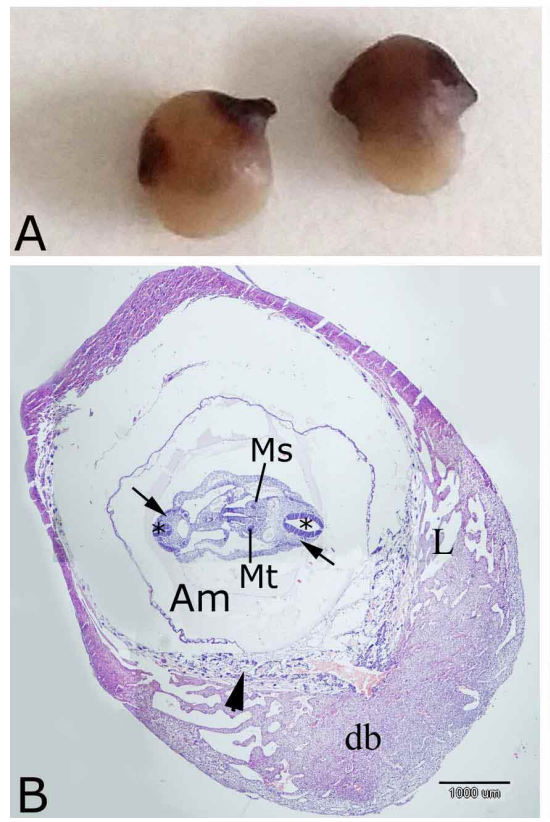

Treated (E10)

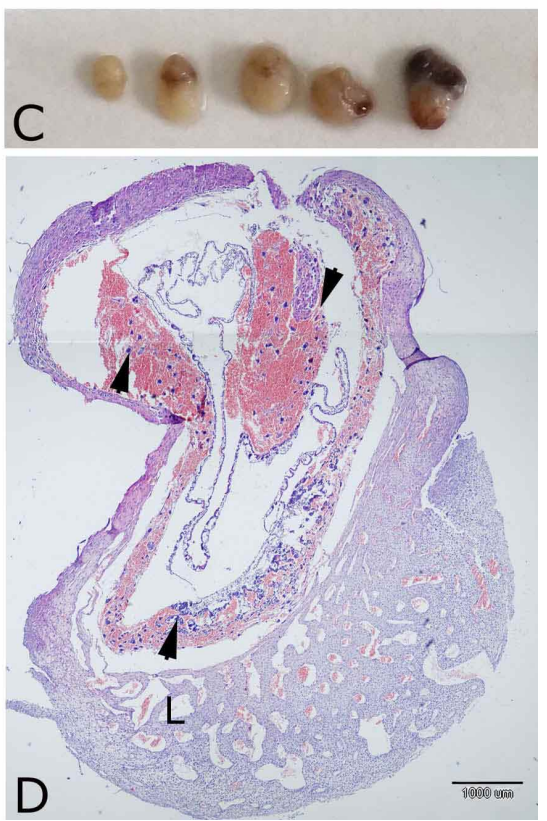

Fig. 4. E-10 Khat treatment outcome. (A): Control embryos at day 10 of pregnancy in their placenta showing normal development with the embryos nearly of equal size and similar shape. (B): Sagittal section through an embryo in (A) showing normal development of the somites (arrows) and neural tube (asterisks). (C): Embryos from Khat-treated mothers with different size and shape. (D): Sagittal section through an embryo in (C) showing delayed neural tube and somite development with the trophoblast giant cells of different size and shape (arrowheads). Am, amniotic cavity; db, decidua basalis; L, Labyrinth; Mt, metanephros; Ms, mesonephros. Haematoxylin and Eosin stain, B\&D (scale bar $=100 \mu \mathrm{m}$ ).
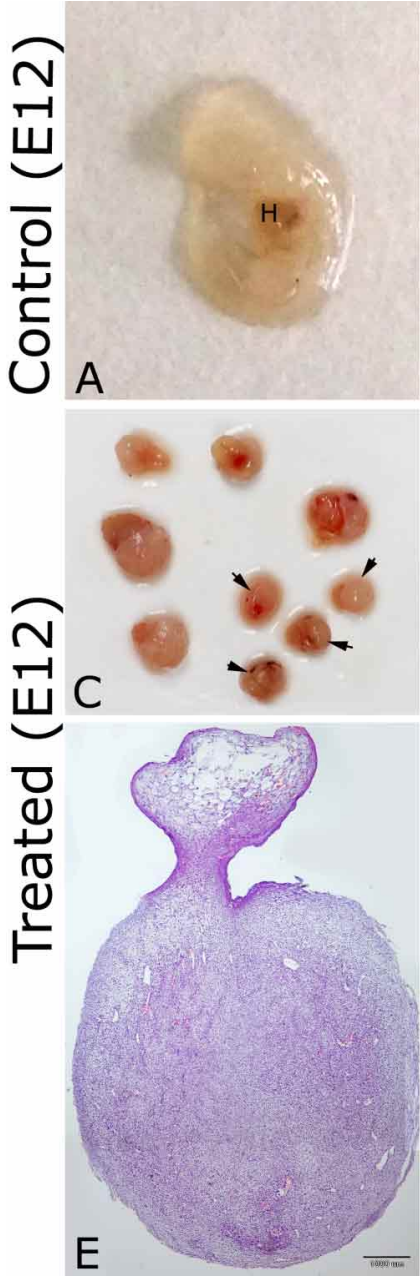

B
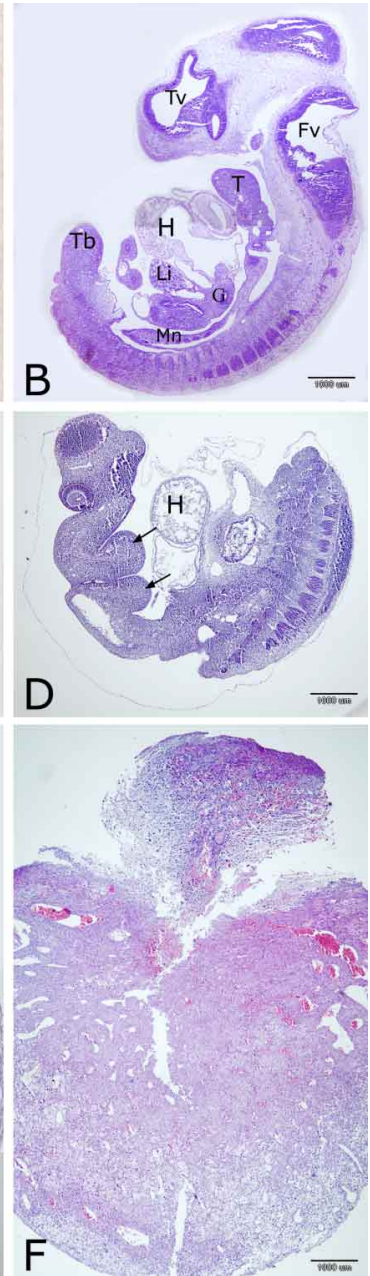

and shape (Fig. 5C) and opened visceral pouches (Fig. 5D). Some of the embryos were resorbed (Fig. 5C) which appeared as a cellular aggregation in their placenta (Figs. 3E-F).

At day 14 (Fig. 6), 15 (Fig. 7) and 16 (Fig. 8) of pregnancy, control embryos showed normal morphology (Figs. $6 \mathrm{~A}, 7 \mathrm{~A}$ and $8 \mathrm{~B}$ ) as well as normal histological internal organs development including brain, nose, heart, lung, liver, gut, and tail buds (Figs. 6B, 7B, and 8C). On the other hand, Khattreated embryos appeared morphologically abnormal and different in shapes and sizes (Figs. 6C, 7C, and 8E). A number of the Khat-treated embryos showed normal morphology (40 $\%$ ) were smaller in size (Figs. 6C, 7C and 8D-E). However, some of these embryos suffered from interrupted neural tube (Fig. 6D), undifferentiated brain vesicles (Fig. 6E) and incomplete closure of the brain flexures (Fig. 7E). Other Khat-

Fig. 5. E-12 Khat treatment outcome. (A): Control embryos at day 12 of pregnancy showing normal development of different organs. (B): Sagittal section through the embryo in (A) showing normal development with closed visceral arches and cervical sinuses; tongue and limb bud, head folds are particularly prominent and proper neural closure occurred. (C): Embryos from the Khat-treated mothers appeared abnormal with different size and shape and opened neural groove (arrowheads), some of the embryos were resorbed (double arrowheads). (D): Sagittal section of an embryo in (C) showing opened visceral pouches (arrows) and abnormal head development. (E, F): Sagittal sections through absorbed embryos, which appeared as a collection of different types of cells in their placenta. Fv, fourth ventricle; G, gut; H, heart; Li, liver; Mn, mesonephros; Tv, third ventricle; T, tongue; Tb, tail bud. Haematoxylin and Eosin stain, B, $\mathrm{D}, \mathrm{E} \& \mathrm{~F}($ scale bar $=100 \mu \mathrm{m})$. 


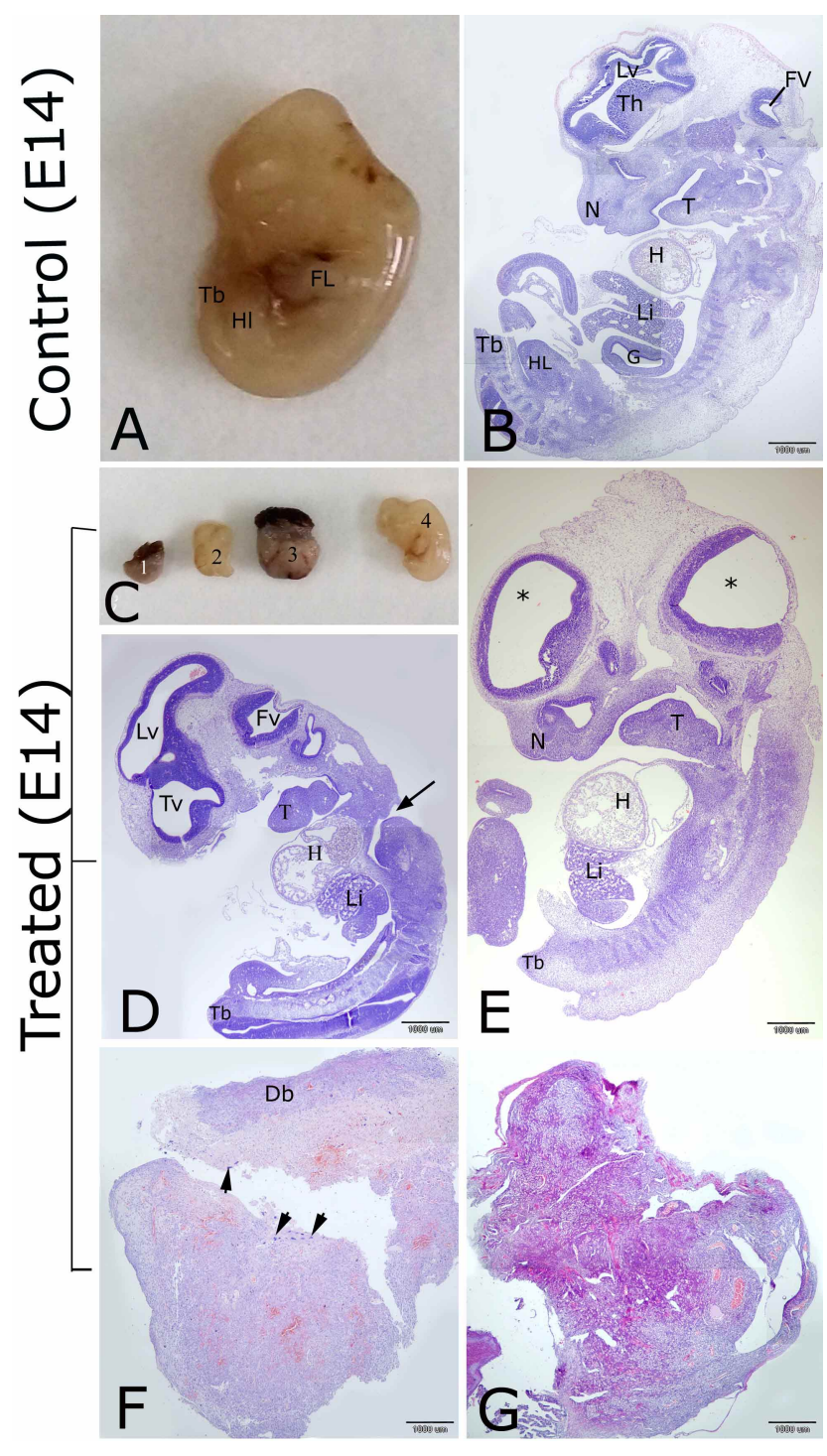

Fig. 6. E-14 Khat treatment outcome. (A): Control embryo at day 14 of pregnancy showing normal development of different organs. (B). Transverse section through the embryo in (A) showing normal development of all embryonic organs. (C): Embryos from the Khat-treated mothers appeared varied in shape and size; some of these embryos were resorbed $(\mathrm{C}, 1)$, with severe morphological abnormalities (C, $2 \& 3)$. A number of these embryos appeared normal but smaller in size (C, 4). (D): Sagittal section of embryo in $(\mathrm{C}, 4)$ showing disrupted neural tube development (arrow). (E): Sagittal section showing an example of normally looking Khat-treated embryo but with undifferentiated brain vesicles (asterisks). (F, G): Sagittal sections through Khat-treated embryos with no visible embryonic tissues observed in the deciduae. Db, decidua basalis; N, Nose snout projection; Fv, fourth ventricle; $\mathrm{H}$, heart; $\mathrm{Fl}$, forelimb; $\mathrm{Hl}$, hind limb Li, liver; Lv, lateral ventricle; T, tongue; Tb, tail bud; Th, Thalamus. Haematoxylin and Eosin stain, B \& E- G (scale bar=100 $\mu \mathrm{m})$.

treated embryos showed severe teratogenic effects including loss of recognizable internal organ structures with some of the deciduae had no visible embryonic tissues (Figs. 6F-G, $7 \mathrm{D}, 8 \mathrm{~F}, \mathrm{G})$. Compared to the number of the control uteri, at least $(60 \%)$ embryos were reabsorbed in each treated pregnant mother (Figs. 1 and 8A, D).

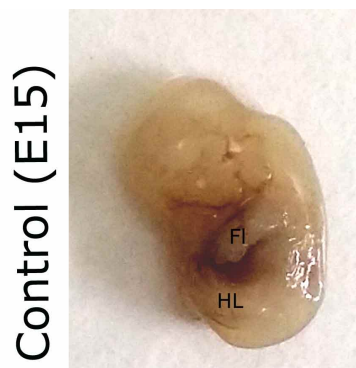

A

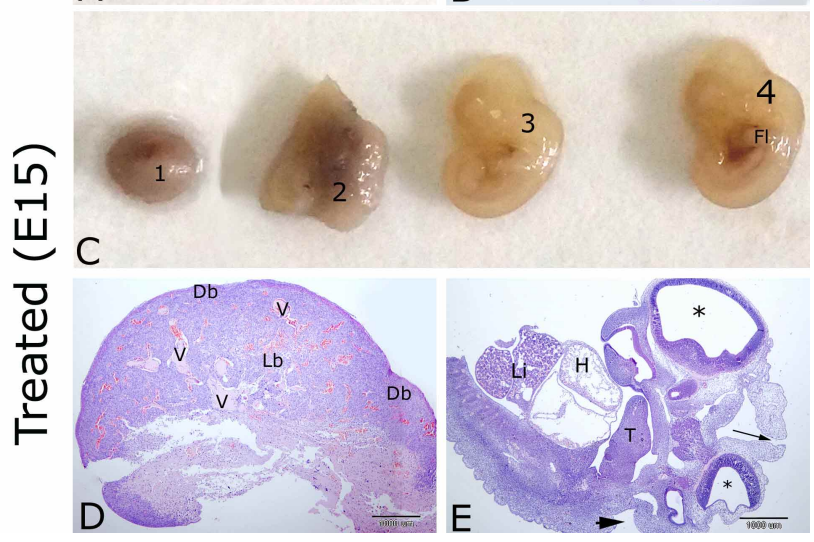

Fig. 7. E-15 Khat treatment outcome. (A): Control embryo at day 15 of pregnancy showing normal development of different organs. (B): Sagittal section through the embryo in (A) showing normal development of all embryonic organs. (C): Embryos from the Khattreated mothers showing variation in size and shape some of which were resorbed $(C, 1)$ and others with smaller in size (C, 3 and 4). $(\mathrm{D}, \mathrm{E})$ : Sagittal sections of Khat-treated with no recognizable embryonic structures in decidua (D) and/or incomplete closure of the brain flexures (E, arrow). $\mathrm{Db}$, decidua basalis; Fv, fourth ventricle; Fl, forelimb; Hl, hind limb bud; L, Labyrinth; Li, liver; Lu, lung bud; N, Nose snout projection; Tv third ventricle; T, tongue. Haematoxylin and Eosin stain, B, D \& E (scale bar=100 $\mu \mathrm{m}$ ).

\section{DISCUSSION}

The current study shows that Khat has adverse effects on embryos at the early stages of development after oral administration of the pregnant mothers with $100 \mathrm{mg} / \mathrm{kg}$ body weight. Such treatment led to a highly significant increase in the number of the resorbed embryos compared to the control as well as a highly significant difference in the number of live embryos between the embryos of the control and Khat 


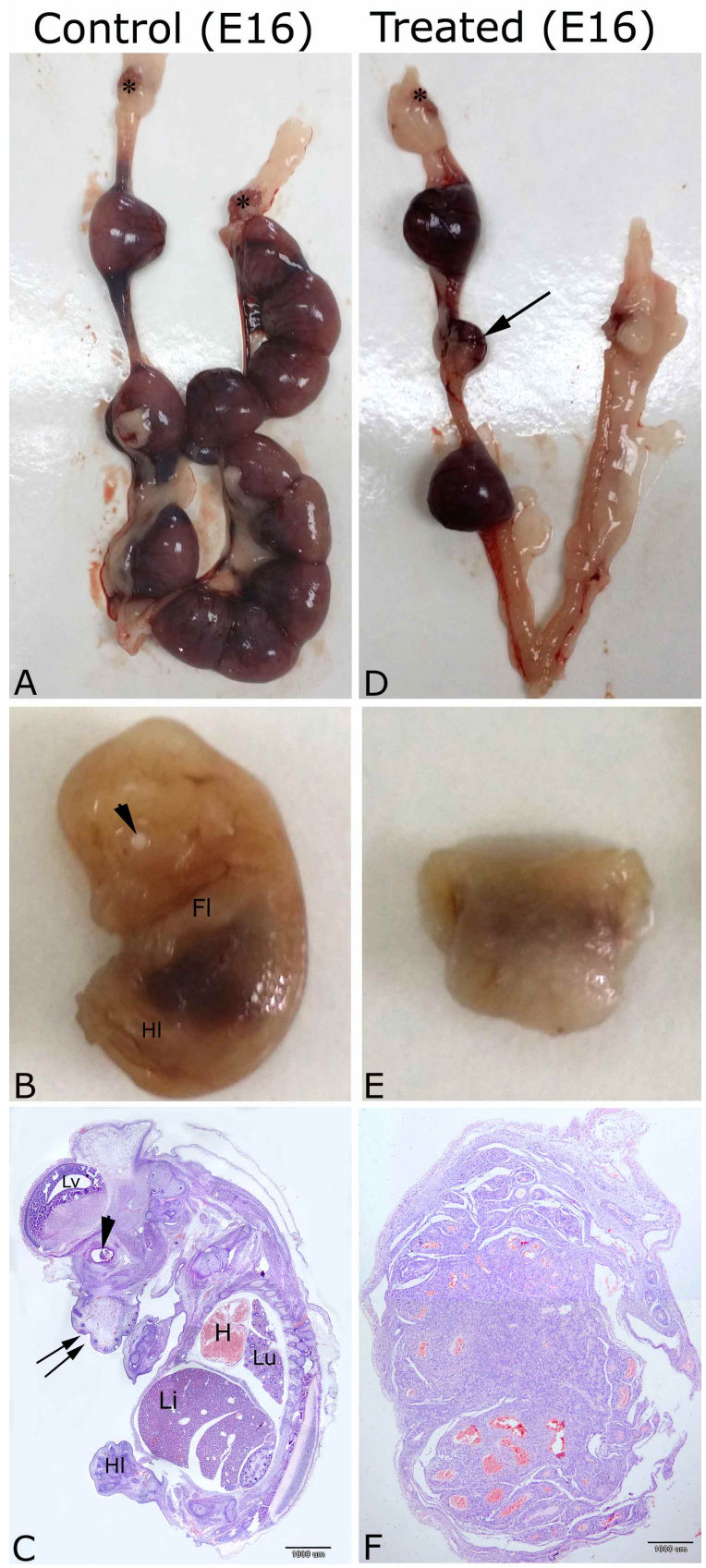

Fig. 8. E-16 Khat treatment outcome. (A) Dissected reproductive tract of a control pregnant rat at day 16 showing considerable number of normally looking embryos in the uterus. (B) An embryo dissected out from the uterus in (A) showing normal looking embryo with normal organ structures. (C): Sagittal section of the embryo in (B) showing normal internal embryonic structures. (D): Dissected reproductive tract of day 16 of pregnancy showing resorbed embryo (arrow) in the uteri of the treated mothers. (E): Reabsorbed embryo appeared morphologically abnormal. (F): Sagittal section through the resorbed embryo showing undifferentiated embryonic tissue. Arrowheads in (B) and (C) indicate the eye; double arrows in (C) indicate the nose snout projection, asterisks in (A) and (D) indicate the ovaries. Fl, forelimb; $\mathrm{Hl}$, hind limb Li, liver; Lu, lung bud; Lv, lateral ventricle. Haematoxylin and Eosin stain, C \& F (scale bar=100 $\mu \mathrm{m})$. treated mothers. Several studies have shown that Khat extract has a profound effect on cell proliferation and may be responsible for chromosomal and embryonic abnormalities (Islam et al.; Kassie et al., 2001; Masood \& Al-Mansoob, 2015; Muema et al., 2016; Nakajima et al., 2017). A study on pregnancy outcome on women who chewed Khat during pregnancy showed a significant increase in low-birth-weight full-term infants among the offspring in comparison to women who were non-chewers during pregnancy (Eriksson $e t$ al.). Khat chewing during pregnancy has a negative impact on maternal and fetal wellbeing (Abdel-Aleem et al.). The neonates of Khat chewing mothers during pregnancy had a significant decrease in all neonatal parameters in comparison with those of mothers who did not chew Khat during pregnancy such as reducing total fetal fat and weight and by inducing some changes in the chemical composition of fetal organs, particularly the liver, heart and kidneys. This effect was attributed to depletion of carbohydrate material and suppression of DNA and protein synthesis in the fetal organs (Abd-El-Aziz \& Ahmed).

In the current experiment, we did not study the maternal toxicity of Khat since this was addressed by Islam et al. who showed that there was no change in the food efficiency index during treatment (days 6-15 of gestation) and the reduction in the food intake had no effect on fetal growth during the early stages of development. These findings were supported by Jansson et al. who reported that there was no correlation between fetal weight and placental blood flow in guinea pigs at the early stages of development.

From the results of the present work, we found many teratogenic effects at the early stages of development resulted from the oral administration of Khat during rat pregnancy including opened neural groove and visceral pouches, discontinuity in the neural tube, undifferentiated brain vesicles and incomplete closure of the brain flexure. Similar study was performed by Islam, et al. but they analyzed the teratogenic effects of Khat in full term fetuses. Khat induced apoptotic changes in liver and kidney cells (Ageely et al.; Ageely \& Abou-Elhamd) by sustained activation of the JNK pathway, which in turn resulted in increase in cell apoptosis (Abid $e t$ al., 2013). In addition, it had cytotoxic effects on cultured mammalian cells (Al-Ahdal et al., 1988). Many chemotherapeutic agents have teratogenic effects and they inhibit DNA synthesis but the relationship between them is not clear (Wilson et al., 1977; El Gendy et al., 2015). However, Celiloglu et al. (2000) reported that inhibition of DNA synthesis with both hydroxyurea and busultan causes growth retardation and congenital malformation. Khat has cytotoxicity and inhibits DNA and RNA synthesis in cultured mammalian cells (Al-Ahdal et al.) and this could be the reason for the congenital malformations we observed in our experiments. 
Our study does not cover the molecular causes for the embryo toxicity and teratogenicity and hence we suggest further molecular-based studies including target gene and protein pathway(s) analysis such as in situ hybridization, proteomics and/or immunostaining to unravel the impaired genes due to Khat treatment. In conclusion, oral administration of Khat at $100 \mathrm{mg} / \mathrm{kg}$ body weight had adverse embryonic effects.

ACKNOWLEDGMENTS. Authors are grateful to the technical staff of the Biology Department, Faculty of Medicine, Jazan University, for their help and valuable technical assistance for carrying out this study. We would like to thank the animal house staff at the Faculty of Medicine, Jazan University. The project was funded by Dean of the Scientific Research, Jazan University (Ref: JUP7//00046), under the name of Dr. Alaa Abou-Elhamd.

ABOU-ELHAMD, A. S.; AGEELY, H.; ABU-ELMAGD, M. \& ZAYED,A. E. Catha edulis forks modera los efectos embriotóxicos en ratas: Un estudio experimental. Int. J. Morphol., 36(3):10871094, 2018.

RESUMEN: Catha edulis (Khat) es una planta floreciente. Una alta proporción de la población adulta en la Península Arábiga y el Cuerno de África la mastica por su efecto estimulante. El objetivo del presente estudio fue investigar los efectos embriotóxicos y teratogénicos del extracto de Khat utilizando 60 ratas hembras preñadas. Estas se dividieron en un grupo tratado con extracto de Khat y un grupo control. El extracto metanólico de Khat se administró por vía oral al grupo tratado 4 días antes del apareamiento y hasta el día 16 de preñez con una dosis de $100 \mathrm{mg}$ / kg. Los resultados mostraron que una cantidad significativa de embriones de las madres tratadas con Khat tenían malformaciones y eran diferentes en tamaño y forma en comparación con los embriones de las madres del grupo control. En el día 8 de preñez, los embriones malformados tenían capas primitivas mal desarrolladas. Para el día 10 de preñez, el tubo neural y el somito no se formaron en comparación con los embriones del grupo control. En etapas posteriores de la preñez, los embriones de las madres tratadas con Khat parecían severamente anormales con surcos neurales abiertos y bolsas viscerales. También se observaron alteraciones en el desarrollo normal del tubo neural, vesículas cerebrales indiferenciadas y el cierre incompleto de las flexiones cerebrales en estos embriones. Se observó un aumento altamente significativo en el número de embriones reabsorbidos de las madres tratadas con Khat $(\mathrm{P}<0,01)$. Los embriones reabsorbidos aparecieron como una colección celular en su placenta con algunas de sus deciduas sin tejidos embrionarios visibles. Khat indujo efectos embriotóxicos y afectó severamente el desarrollo embrionario normal temprano en la rata.

PALABRAS CLAVE: Khat; Toxicidad embrionaria; Teratogenicidad; Análisis morfológico e histológico; Rata.

\section{REFERENCES}

Abd-El-Aziz, G. S. \& Ahmed, K. Neonatal parameters and placental weight in khat-chewing mothers in Jimma. Ethiop. J. Health Sci., 8(1):39-45, 1998. Abdel-Aleem, A. M.; Abdulkader Al-Aghbari, A. A.; Mohamed Mustafa, S. A.; Ali Ahmed Nasr, A. M. \& Abdulbari Assad, M. M. Khat chewing during pregnancy: an insight on an ancient problem. Impact of chewing khat on maternal and fetal outcome among Yemeni pregnant women. $J$. Gynecol. Neonatal Biol., 1(2):28-31, 2015.

Abid, M. D.; Chen, J.; Xiang, M.; Zhou, J.; Chen, X. \& Gong, F. Khat (Catha edulis) generates reactive oxygen species and promotes hepatic cell apoptosis via MAPK activation. Int. J. Mol. Med., 32(2):389-95, 2013.

Ageely, H. M. \& Abou-Elhamd, A. S. Morphological and apoptotic changes in the kidney of rats after Khat extract administration. Int. J. Adv. Life Sci., 8(2):145-72, 2015

Ageely, H. M.; El-Nagar, M. M.; Abouelmagd, A.; Abou-Elhamd, A. S.; Kelany, M. E. \& Patil, B. R. Khat extract mediated morphological and histochemical alterations in rat liver. Int. J. Adv. Res., 2(11):971-80, 2014.

Al-Ahdal, M. N.; McGarry, T. J. \& Hannan, M. A. Cytotoxicity of Khat (Catha edulis) extract on cultured mammalian cells: effects on macromolecule biosynthesis. Mutat. Res., 204(2):317-22, 1988.

Al-Habori, M. The potential adverse effects of habitual use of Catha edulis (khat). Expert Opin. Drug Saf., 4(6):1145-54, 2005.

Al-Hebshi, N. N. \& Skaug, N. Khat (Catha edulis)-an updated review. Addict. Biol., 10(4):299-307, 2005.

Al-Motarreb, A.; Baker, K. \& Broadley, K. J. Khat: pharmacological and medical aspects and its social use in Yemen. Phytother. Res., 16(5):40313, 2002.

Brenneisen, R.; Fisch, H. U.; Koelbing, U.; Geisshüsler, S. \& Kalix, P. Amphetamine-like effects in humans of the khat alkaloid cathinone. $\mathrm{Br}$. J. Clin. Pharmacol., 30(6):825-8, 1990.

Carvalho, F. The toxicological potential of khat. J. Ethnopharmacol., 87(1):12, 2003.

Celiloglu, M.; Altunyurt, S. \& Undar, B. Hydroxyurea treatment for chronic myeloid leukemia during pregnancy. Acta Obstet. Gynecol. Scand., 79(9):803-4, 2000.

Dimba, E. A.; Gjertsen, B. T.; Bredholt, T.; Fossan, K. O.; Costea, D. E.; Francis, G. W.; Johannessen, A. C. \& Vintermyr, O. K. Khat (Catha edulis)-induced apoptosis is inhibited by antagonists of caspase- 1 and -8 in human leukaemia cells. Br. J. Cancer, 91(9):1726-34, 2004.

El Gendy, M. M.; Kandil, A. M.; Helal, M. A.\& Zahou, F. M. The teratogenic effects of imatinib mesylate on rat fetuses. Toxicol. Rep., 2:654-63, 2015.

El-Menyar, A.; Mekkodathil, A.; Al-Thani, H. \& Al-Motarreb, A. Khat use: history and heart failure. Oman Med. J., 30(2):77-82, 2015.

Eriksson, M.; Ghani, N. A. \& Kristiansson, B. Khat-chewing during pregnancy-effect upon the off-spring and some characteristics of the chewers. East Afr. Med. J., 68(2):106-11, 1991.

Hassan, N. A.; Gunaid, A. A.\& Murray-Lyon, I. M. Khat (Catha edulis): health aspects of khat chewing. East Mediterr. Health J., 13(3):70618, 2007.

Islam, M. W.; al-Shabanah, O. A.; al-Harbi, M. M. \& al-Gharably, N. M. Evaluation of teratogenic potential of khat (Catha edulis Forsk.) in rats. Drug Chem. Toxicol., 17(1):51-68, 1994.

Jansson, T.; Kristiansson, B. \& Qirbi, A. Effect of the khat alkaloid (+)norpseudoephedrine on uteroplacental blood flow in the guinea pig. Pharmacology, 34(2-3):89-95, 1987.

Jerah, A. B. A., Bidwai, A. K. \& Alam, M. S. A review of the history, cultivation, chemistry, pharmacology and adverse health effects of Khat. Int. J. Appl. Nat. Sci., 6(3):2319-4014, 2017.

Kalix, P. Catha edulis, a plant that has amphetamine effects. Pharm. World Sci., 18(2):69-73, 1996.

Kassie, F.; Darroudi, F.; Kundi, M.; Schulte-Hermann, R. \& Knasmüller, S. Khat (Catha edulis) consumption causes genotoxic effects in humans. Int. J. Cancer, 92(3):329-32, 2001. 
ABOU-ELHAMD, A. S.; AGEELY, H.; ABU-ELMAGD, M. \& ZAYED, A. E. Catha edulis forsk mediates embryotoxic effects in rats: An experimental study Int. J. Morphol., 36(3):1087-1094, 2018.

Kimani, S. T.; Patel, N. B. \& Kioy, P. G. Effect of single and daily khat (Catha edulis) extract on locomotor behaviour in CBA mice. Sci. Res. Essays, 3(5):187-96, 2008.

Masood, M. S. A. \& Al-Mansoob, M. A. K. The impact of chewing khat during pregnancy on foetal death history. Int. J. Nov. Res. Healthc. Nurs., 2(2):28-31, 2015.

Muema, E.; Kinyanjui, P.; Mbaria, J.; Nguta, J.; Chepkwony, S.; Kamau, J.; Onkoba, N.\& Nyachieo, A. Toxicity and safety of khat (Catha edulis) consumption during pregnancy using olive baboons (Papio anubis) as experimental models: A prospective randomised study. Greener J. Epidemiol. Public Health, 4(3):61-70, 2016.

Nakajima, M.; Jebena, M. G.; Taha, M.; Tesfaye, M.; Gudina, E.; Lemieux, A.; Hoffman, R. \& al'Absi, M. Correlates of khat use during pregnancy: A cross-sectional study. Addict Behav., 73:178-84, 2017.

Wilson, J. G.; Fraser, F. C. \& Ritter, E. J. Handbook of Teratology. Vol. 2. New York, Plenum Press, 1977.
Corresponding author:

Alaa Sayed Abou-Elhamd, Ph.D.

Department of Anatomy

Histology and Embryology,

Faculty of Veterinary Medicine

Assiut University

Assiut

EGYPT

Email: alaa88@yahoo.com

Received: 07-03-2018

Accepted: 25-05-2018 